\title{
Recruitment to the Norwegian fishing fleet: storylines, paradoxes, and pragmatism in Norwegian fisheries and recruitment policy
}

Signe Annie Sønvisen

Correspondence: signe.a.sonvisen@uit.no

Norwegian College of Fishery Science, University of Tromsø, N-9037, Tromsø, Norway

\begin{abstract}
The majority of actors in the Norwegian fisheries consider recruitment of fishers to be the main future challenge for the Norwegian fishing fleet. As fleet recruitment is a highly politicized field, the problem of how to mitigate the recruitment problem is a subject of heavy debate. Some argue that recruitment problems are caused by low fleet profitability, while others argue that recruitment problems are caused by fleet restructuring polices.

This article aims to explore the recruitment phenomenon. Thus, it examines the relationship between recruitment discourse and recruitment policies and practices. Discourse analysis is used to show how diverging storylines about recruitment result in incoherent recruitment policy. The article concludes that while current recruitment policies are heavily influenced by ideology, the answer to creating more efficient recruitment policies may lie in a more pragmatic approach.
\end{abstract}

Keywords: Recruitment; Paradox; Employment; Fishing fleet; Fisheries policy; Discourse analysis; Storyline

\section{Background}

Recruitment-creating fisheries actors

For centuries, fisheries have been an important industry along the Norwegian coast in terms of income and employment. Initially, the fisheries were open access. Anyone could more or less freely establish as fishers. However, the fisheries have increasingly been closed in the last fifty years, mainly due to stock collapse. As a result, fewer people and vessels are directly involved in the fisheries (McCay 1999; Holm 2001; Wright 2001; Caddy and Cochrane 2001; Apostle et al. 2002; Hersoug 2005). Alongside effort-reducing policies and the reduced participation, discussions regarding recruitment problems in the Norwegian fishing fleet surfaced. Presently, general consensus holds that there is a fleet recruitment problem, but there is no consensus as to what this problem entails. Some argue that recruitment problems are due to low fleet profitability and wages (MFCA 2008). Others argue that restructuring policies, increased quota tradability, and higher cost of entry have led to recruiting problems (Kyst og Fjord 2011). Due to different understandings of the recruitment problem, different interest groups push recruitment policies in different ideological directions (Stone 1989). As a result, measures to combat recruitment problems tend to contradict one 
another, creating what Sønvisen et al. (2011) referred to as the recruitment paradox. However, paradoxes and dilemmas in policy formation and management are more the rules than the exceptions (Jentoft et al. 1998; Singleton 2000; Suarez et al. 2008; Wilson 2009). This article aims to cut through the complexity of fleet recruitment to better understand fleet recruitment and the recruitment problem. Moreover, this article will explore the gap between rhetoric and practice in order to expose the contingent nature of policy processes (Hewitt 2009).

Although this article investigates recruitment to the Norwegian fishing fleet, the findings are relevant beyond Norway. As in Norway, European fisheries management has been oriented towards capacity reduction and fleet restructuring. Restructuring policies emanate from expectations about future fisheries concerning who shall fish, how many people shall fish, and what type of fishers will be needed. Thus, discussions about management policies, restructuring policies, and recruitment policies must intertwine. Consequently, in addition to recruitment, this article also discusses management policies and recruitment policies, when they are of relevance.

The term recruitment has different meanings. ${ }^{a}$ In biology, recruitment is defined as, "The process of adding new individuals to a population" (Merriam-Webster Online 2012); in business, it is defined as, "The process of identifying and hiring the bestqualified candidate" (WebFinance, Inc. 2012). However, I feel that these definitions are too limiting. In this article, the term recruitment also includes the social process preceding the occupational choice, such as socialization, training, and transfer of knowledge. Recruitment may therefore be explained by individualistic rational choices, but also by socially motivated choices (Jentoft and Wadel 1984).

As stated above, this article will explore the phenomenon of recruitment. It examines the relationship between storylines, discourse coalitions, and recruitment policies, and shows how policy actors construct meaning around recruitment and act upon the constructed meaning (Hajer and Versteeg 2005). In particular, it will show that fleet recruitment is not simply about numbers, but also about rhetoric and policy formation. Thus, the article will first identify the recruitment storylines and discourse coalitions rhetorically mobilized in fisheries and recruitment policy debates. It will then explore how these storylines manifest in the fisheries and recruitment policies we observe, and the implications of the coexistence of several storylines in policy making. Finally, the article will discuss the policy paradox and how to live with it.

The article will contribute to a deeper understanding of why a more pragmatic approach is needed in policy making. In accordance with Ostrom (1990), the article will illustrate that storylines and images should not be used as an ipso facto foundation for policies and regulations. The article will also have a methodological contribution, as Norwegian fisheries policy has not previously been studied using the method of discourse coalitions and storylines.

The article is organized as follows: after this brief introduction, section two describes the method and theory used and discusses relevant developments in Norwegian fisheries management. Section three describes and develops the storylines and the discourse coalitions. As contemporary storylines are products of the past, each description will start in the 1950s, when fleet recruitment problems first surfaced, even though the article primarily focuses on the period after the turn of the millennium. In section four, the different storylines and discourse coalitions will be discussed in relation to practical 
fisheries, with recruitment as the case. The article concludes that the existence of several diverging storylines leads to incoherent recruitment policies and that storylines founded in ideologies lock policies into narrow courses of action. In a complex reality, the storylines upon which we build policies have to be revised.

\section{A relational approach to study fishers and policy A relational approach to recruitment}

This article is situated within the relational sociology of the Actor-Network Theory (ANT), which sees the world as a series of networks of stable and unstable relationships. Thus, fisheries actors get their content and identity in relation to other actors (Johnsen 2004; Latour 2005). This article also utilizes discourse analysis (DA), much in the way that Hajer $(2012,1995)$ did, and makes particular use of storylines and discourse coalitions (Neumann 2001; Næss 2003; Hajer 2012).

Because discourses may be shared across networks and actors from different fractions may use the same repertoires for framing their arguments, Hajer offers a dynamic and relational approach that is compatible with ANT (Hajer 1995,12-13, 44; Næss 2002). The approach here is also inspired by Foucault's approach to DA, in which a statement is also linked to a network of pre-existing statements, tools, practices, institutions and other statements (Schaaning 1997,198). Storylines are thus "not strictly examined for their semantic core but used rather vaguely with different actors attaching different meaning to them" (Späth 2012).

To deal with complexity, we describe the world around us using simplifying narratives, such as storylines (Hajer 1995). In the realm of fleet recruitment, a particular storyline is embedded and reproduced among members of a particular group of actors, a discourse coalition. Through shared storylines, the discourse coalitions define problems, positions actors, distribute responsibility and offer solutions to the recruitment problem (Hajer 1995, 2012). However, due to the simplistic nature of storylines, they may conceal as much as they disclose. Hence, recruitment policies based solely on storylines and not on realistic assessments of human behaviour may give results substantially different from those intended (Ostrom 1990, 23-24). In addition, recruitment is about politics. Hence, fisheries recruitment is an argumentative game, in which conflict arises when coalitions struggle for discursive hegemony and domination (Hajer 1995; Kooiman 2003; Bingham 2010; Jentoft et al. 2010; Späth 2012). A powerful coalition is one whose storyline is widely adopted and is perceived as a correct translation of a phenomenon (Næss 2002).

Hajer distinguishes two processes by which a discourse becomes dominant: structuration or institutionalization. Structuration of a discourse is when a particular conceptualization of a phenomenon seems traditional, natural, or normal. In order to be considered legitimate, the conceptualization must be the product of a particular line of argument. Institutionalization of a discourse occurs when the discourse is manifested in specific institutional or organizational arrangements, such as planning procedures or monitoring arrangements (Späth 2012).

\section{Norwegian fisheries management}

Two main theoretical perspectives have influenced Norwegian fisheries policy and management. One is the perspective offered by Hardin (1968) and Gordon (1954), 
referred to as the resource management perspective, which have influenced management thinking all over the world (McGoodwin 1990). ${ }^{\mathrm{b}}$ The actors in this perspective are interpreted to be either individualistic, economic rational appropriators in a common with open access resources or actors locked into a system that produces rationality that break down the system. Although the latter interpretation seems to be most in line with Hardin's arguments, the first interpretation has become the prominent understanding of fisheries actors in Norwegian fisheries policy (White Paper WP No. 20 2002-2003).

The other perspective to influence Norwegian fisheries management is the one offered by the local community paradigm (Brox 1966; Jentoft and Wadel 1984; Hersoug et al. 1993). This local community perspective sees actors as acting rationally within socially constructed frameworks, using rationalities other than purely economic ones. The fisher, the fisheries, and the local communities are mutually dependent systems in which market relations and the traditional economic understanding of rationality is only a part of the total rationality (Johnsen 2004). In relation to this article, the actor perspective is central when it comes to defining fisheries and recruitment policies.

Figure 1 below summarizes the two dominating perspectives within the argumentative game concerning Norwegian fisheries management, the effects of fisheries management, and the resulting management paradox. The first is the resource management perspective, in which management measures such as rights and quotas are solutions to overexploitation and low fleet profitability. The desired result of resource management is to have fewer fishers and improved profitability for the involved fishers, which is to be achieved through individualistic and economic reasoning.

The second is the local community perspective, which considers the management measures outlined by the resource management perspective to interfere in healthy and well-functioning economic systems. According to the local community perspective, management measures resulting in fewer fishers will cause a disintegration of the employment systems upon which fishery communities depend. From the local community perspective, management problems are solved through collective and socially oriented strategies.

Because the two perspectives consider the same actions to cause opposite effects, they create a management paradox, where diverging policies contradict and counteract each other.

\section{Extraction of storylines}

The analytical method used in this article is a form of discourse analysis (DA) inspired by Hajer (2012) and Woodak (2007). First an extensive literature review to get a grasp of the recruitment debate was carried out. I then created a chronology of arguments and actors within the discourse using previous research, official reports (Green Papers [NOU]), government documents (such as White Papers [WP]), law documents, newspaper articles, web pages, internet blogs, and so on.

Between the spring of 2010 and the spring of 2012, I went into the field and conducted sixty one interviews with 106 informants. Informants were active fishers and vessel owners, shipping companies, invested parties, fisheries managers, fish buyers, municipality representatives, politicians, and students at a vocational fisheries high school. The informants hailed from geographic areas in which the fisheries industry is an important industry: Måløy/Stad (south), Ålesund (south), Lofoten (mid), Steigen (mid), and Båtsfjord (north). 


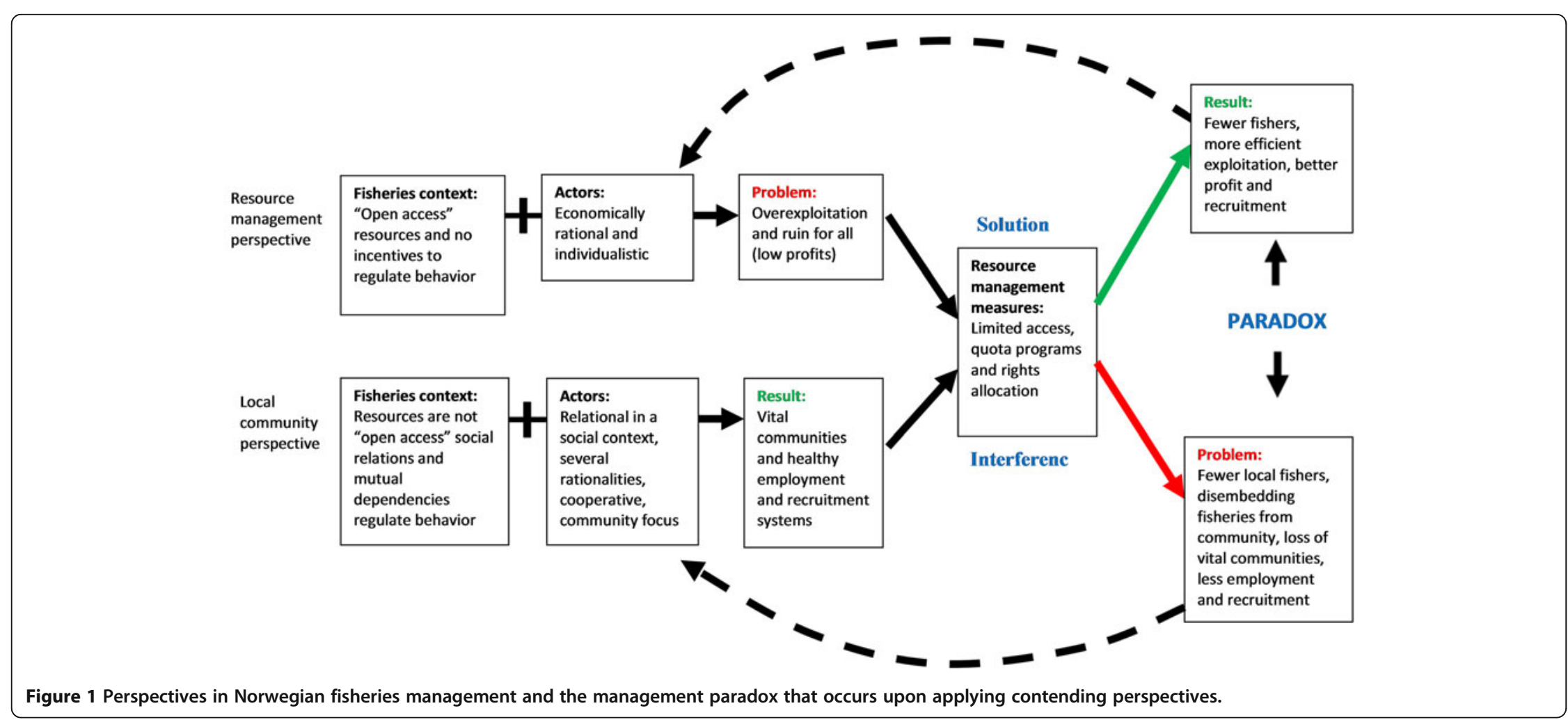


Informants were chosen using snowball sampling, which is a non-probability sampling technique used to find informants with particular traits or knowledge. One informant directs the researcher to others, who in turn provide others, and the sample grows quickly among this network (Biernacki and Waldorf 1981). The interviews were unstructured and the majority were in-person. A number of telephone interviews were also carried out. An interview guide was used to keep the conversations on-track. Questions were open-ended and aimed at obtaining life histories. Informants were initially asked to tell how they were recruited into the fisheries and how they were trained. Informants were further asked to describe local recruitment patterns and challenges. In order to tie responses to current politics, issues regarding the present fisheries and restructuring policies, and their effects upon recruitment, were also discussed.

The secondary data, from the literature review, was the main basis for developing the history of the recruitment discourse. Both secondary and primary data were used in the analysis of the contemporary discourse. The analysis was driven by the narratives, which were sorted thematically and then chronologically. Narratives were roughly categorized based on what was said about recruitment, the reasons for the recruitment problem, and the solutions to it. For instance, statements such as "low recruitment is caused by poor fleet profitability" and "low recruitment is caused by restructuring policies" were sorted into two different categories. Three storylines with associated discourse coalitions emerged: one tied to economic efficiency and business interests, one tied to regional development and community values; and a third that mix repertoires of the two first. The discursive strategies of the discourse coalitions were also explored to see who argued what and to check for consistency. Finally, the study explores discursive hegemony based on Hajer's concepts of institutionalization and structuration.

\section{The recruitment discourse}

Using the data collected and DA, it is time to assess what storylines and discourse coalitions emerged. Three storylines materialized within the recruitment discourse: the profitability storyline, the community storyline, and the pragmatic-fisher storyline, which were associated with the profitability coalition, the community coalition, and the pragmatic-fisher coalition, respectively. The following sections will describe the developments of each of the storylines.

\section{The profitability coalition: profitability as the solution to the recruitment problem}

According to recruitment narratives, the first storyline that materialized was the profitability storyline. This storyline is closely related to the resource management perspective outlined in Figure 1. The argument of those who contributed to the profitability storyline is that low profitability, accompanied by low salaries and a low rate of fleet renewal, causes unsatisfying work conditions and makes the fleet less competitive, which in turn leads to recruitment problems. According to them, improved profitability is the key to successful recruitment and can be achieved through fleet rationalization and restructuring. Further, it is assumed that a smaller fleet consisting of larger units will be able to afford bigger crews and that the fleet will then implement shift systems, making work periods more predictable and the fleet more attractive (Hannesson 2005; Norwegian Savings Bank Association 2006; White Paper WP No. 21 2006-2007; DoF 2011; FVOA 2011). A typical profitability 
coalition statement is one such as that provided by the Norwegian Fishing Vessel Owners' Association (FVOA) (2006):

In order for the fishing fleet to become attractive and recruit qualified labour, the general profitability has to improve. Then the entire fleet will be able to offer competitive wages and work conditions ... Reducing costs by reducing the number of fishing vessels will increase the earnings on-board each remaining vessel, which is the most important contribution to increase profitability in the fishing fleet in the long-term.

The profitability storyline is what keeps the profitability coalition together. This coalition includes actors such as the Ministry of Fisheries and Coastal Affairs (MCFA), the Directorate of Fisheries (DOF), the Norwegian Fishermen's Association (NFA), the Fishing Vessel Owners' Association (FVOA), economists, finance and banking interests, political parties (centre and right), and a number of municipalities and counties in the north and the south. ${ }^{\mathrm{c}}$

Despite coming from a resource biology perspective, the DOF and environmental interest organizations, such as WWF, also subscribe to the overarching profitability storyline (DOF 2008a). These actors argue for continued restructuring to further reduce fleet capacity in order to increase productivity and profitability, and also to secure the resource base (Directorat of Fisheries DoF 2006; World Wildelife Fund WWF 2006). Whereas the majority of those subscribing to this storyline reiterate the profitability-for-business storyline, environmental interests subscribe to a profitability-forconservation storyline. Another actor that has become an important ally in this coalition is the finance and banking sector (Johnsen 2004). Hence, in spite of the coalition members' varying perspectives on the storyline, the overarching meaning remains that profitability is the solution to the recruitment problem.

The profitability storyline first surfaced after World War II (WWII). At the time, fishers were seen as producers within a structure, and were expected to act in the best interests of society. Thus, due to fleet overcapacity and low income, fisheries authorities deemed reduced fleet employment as best for society. Hence, youths in fishery regions were encouraged to enter other occupations (White Paper WP No. 10 1947; Holm and Johnsen 1990; Johnsen 2004). In the wake of these attempts to reduce employment, the first reports of recruitment problems followed. The recommended solution to the new challenge was improved profitability:

While the fisheries in the 1930s had such a large surplus of labour that one could talk about an overpopulated sector, it has since the war been difficult to provide adequate crew. Although profitability in the fisheries has improved greatly, many prefer fixed salaries on shore, rather than uncertain seasonal income from fishing. Recruitment to the profession has therefore declined .... The general fisheries policy that aims at improving fisheries' profitability will facilitate a more satisfactory recruitment (White Paper WP No. 62 1953).

From the 1950s until the 1980s, the fisheries underwent vast changes related to industrialization, rationalization, and specialization. Despite the significant decline in the number of fishers in this period (sixty three percent), the fleet still struggled with 
low profitability and policies continually focused on capacity reduction (White Paper WP No. 75 1962-63; White Paper WP No. 18 1977-78; White Paper WP No. 93 1982-83); Johnsen 2004). In the 1980s, the profitability coalition gained influence as policies of economic liberalization flourished and reliance upon market mechanisms increased (Hersoug 1983). This led to a major change in fisheries policies. Prior to the 1980s, coastal employment and settlement were to be secured through government interventions. From the 1980s, employment and settlement were increasingly expected to be secured through a market-oriented, efficient and profitable fleet (White Paper WP No. 93 1982-83; White Paper WP No. 32 1989-90; White Paper WP No. 32 1990-91). Still, despite there being no general fleet recruitment problem in the 1980s, the quickly developing and better-paying petroleum industry began to attract qualified crew from the fisheries industry. To compete, the fleet had to offer competitive wages and work conditions. Hence, fleet recruitment was not only about number of recruits, but was also about the qualifications of these. Thus, improved efficiency and profitability became an even more attractive solution (White Paper WP No. 93 1982-83, 8).

Two developments in the early 1990s strengthened the profitability storyline's position in the recruitment discourse: the collapse of the North East Arctic (NEA) cod stock and the downscaling of the Main Agreement (MA) (Holm 1996). ${ }^{\text {d }}$ In 1989, due to low NEA cod quota and good catchability, the total quota was caught by mid-April. A moratorium was imposed on the coastal fleet, followed by the introduction of fishing rights and quotas the following year. Only those fishers with a certain level of activity in the three preceding years were entitled to participate in the fishery (Maurstad 2000). These changes decreased the number of coastal fishers, as they were intended to. These management measures had their basis in bio-economic theory, which promoted both resource conservation and fleet profitability. From then on, bioeconomic theory and bio-economists became important allies in the profitability coalition (Johnsen 2004).

The other development that strengthened the profitability coalition was the downscaling of the MA and its subsidies. Although the agreement was intended for rationalization and industrialization, it had turned into an economic safety-net for fishers and shielded the sector from efficiency requirements demanded by other sectors (Standal and Aarset 2002). Not only did it maintain overcapacity, it also challenged international trade agreements, especially those with the European Community, which demanded its abandonment (Holm and Johnsen 1990; Holm 1995; Hersoug and Arbo 1997). The transition from being a heavily subsidized industry to an economically efficient sector led to significant structural changes, which also called for improved fleet profitability and reduced participation (Hersoug et al. 2000; White Paper WP No. 21 2006-2007).

Even though developments in the 1990s reduced fleet participation, overcapacity was still riding the fleet in the new millennium. The quota scheme of the 1990s was therefore further developed. Hence, the Labour Party (LP) introduced unit quotas in 2000 and the Conservative Party (CP) introduced the structure quota system (SQS) in 2003 (Innsl.S.nr. 271 2002-2003). ${ }^{\text {e,f }}$ The SQS was highly controversial, and in 2005 the new Minister of Fisheries (Pedersen, LP) flagged a new fisheries policy that would allow local communities to thrive off the resources available in their region (Pedersen 2006). The SQS was temporarily frozen in order to be evaluated. The evaluation concluded 
that Norway at large did not experience any socio-economic problems due to the SQS. Since some fleet segments were still struggling with overcapacity, it was deemed necessary to continue restructuring. The SQS was prolonged and expanded to include vessels as small as eleven meters in length (Innst.S.nr. 238 2006-2007). The Minister of Fisheries thus also became an important ally in the profitability coalition.

There were, however, actors who wanted to go further. The Nordland County Fishermen's Association, the NFA, and the CP suggested that the SQS include the entire coastal fleet-also vessels smaller than eleven meters long-even if this resulted in fewer coastal fishing vessels. They stated that such an action was "necessary to secure profitability and recruitment" (Conservative Party CP 2007). By this time, the majority of the fisheries stakeholders were enrolled in the profitability coalition, calling for fewer fishers and improved profitability.

Although the majority of the fisheries actors agreed that there was a fleet recruitment problem, they did not agree on what this problem actually entailed (White Paper WP No. 20 2002-2003; Johnsen 2004). Fleet recruitment was so heavily debated that the Norwegian government chose to evaluate it in 2006 and 2008 (MFCA 2006, 2008). Both evaluations concluded that there was not a significant fleet recruitment problem. Nevertheless, technological advancements in the marine sector, labour competition with the subsidized oil-supply fleet, and changing regulations in the coastal fleet increased the fleet's demand for specialized crew, such as skippers, navigators, and engineers (Sandberg and Olafsen 2006; Remøy 2011). ${ }^{\mathrm{g}, \mathrm{h}}$ This demand was particularly felt among offshore and larger coastal vessels. Some vessels alleviated the recruitment problems by further technological advances; others took "on-board unqualified youth...or foreigners" (Offshore vessel owner 5 2011). However, the situation might have been worse if it weren't for past fleet restructuring. According to one Chief of Crew 1 (2012), "It was possibly more problematic getting people five years ago, [in 2007], before the fleet restructured. Then there was a bigger recruitment problem and a higher turnover, and possibly more foreign crew." Thus, to attract the best qualified labour to the fleet, the profitability coalition suggested the same solution they had tried before: improving fleet profitability by restructuring further so that the fleet could offer competitive wages and working schemes (Fishing Vessel Owners' Association FVOA 2006).

A storyline receives its strength from the number of actors using it (Næss 2002) and according to Hajer (2012); a discourse becomes dominant through structuration and institutionalization. In general, the profitability storyline dominates general fisheries policy, as a large variety of influential fisheries actors have been enrolled into the profitability coalition's networks (Latour 2005). These actors include bureaucrats, managers, law makers, scientists, resource managers, banks, fisheries organizations, and environmental interests. In addition, the profitability coalition, to some extent, presents their storyline as an unavoidable "fact" through monumental texts and documents, including research papers, WP, NOUs, political programs, and laws and regulations. This is what Hajer (2012) refers to as structuration, when the ideas become taken for granted facts. The structuration of the profitability storyline is partly a result of its alliance with long standing, well known, and widely accepted theories, particularly bio-economic theory, which is the dominant discourse and the ideological foundation of fisheries management (St. Martin 2006). For instance, there is a taken for granted causality between 
profitability and coastal economic activity. As the Norwegian Savings Bank Association said (2006):

In our opinion, the evaluation [Green Paper NOU 2006:16] shows that the restructuring measures ensure a modern and profitable fleet, which is essential for the realization of the Government's objective of sustainable [economic] activity along the entire coast.

The quote above not only shows structuration, but also that proponents of the profitability coalition are increasingly using regional development as a part of their storyline (Momyr 2005), which previously was only found in their opponents' storyline.

The profitability storyline has also increased its dominance, through structuration, as its discursive practices also have penetrated even the smallest coastal fleet (Schaaning 1997), as portrayed by a small-scale vessel owner in Northern Norway:

The [SQS] has made it possible for me to have three people on-board. Otherwise, I would have to fish alone.... [The SQS] has made [fishing] more stable and improved earnings. [It has offered] a more comfortable work situation ... I would like to have an apprentice on-board, if it did not affect profitability (Coastal vessel owner 7).

In addition to structuration, the profitability storyline has also come to dominate general fisheries policies, as it has been institutionalized in organizational practices. For example, through the SQS, the storyline has been locked in a rigid system based on predefined allocation keys and large individual investments (Holm and Nielsen 2007; Standal and Utne 2011; Hajer 2012). Any attempt to change the system is met by great opposition from the majority of stakeholders in the sector, including a large number of small-scale fishers; hence, the storyline's footing within general fisheries policies is strong.

In relation to recruitment, the profitability-discourse has been less successful in affecting recruitment policies. The profitability coalition recognized that the closing of the fisheries and the introduction of rights and quotas caused recruitment of vessels owners to the smallest coastal fleet to decline. The flee recruitment evaluations (MFCA 2006, 2008) suggested two measures to mitigate this effect: providing free quotas in the closed fisheries to young fishers already in possession of a vessel (recruitment quotas) or providing financial support to buy vessels and quotas in the ordinary market (establishment grants) (Prop. $1 \mathrm{~S}$ 2009-2010). In the perspective of the profitability coalition, introducing recruitment quotas would undermine years of restructuring and was not a desired development. Rather, the coalition supported establishment grants, as these would not increase participation. The large majority of the fisheries actors supported this stance (DoF 2008b). The establishment grants, however, were allocated only once, and less than a third of the grants were allocated, due to overly strict requirements for recipients (DoF 2012b). Hence, the establishment grants had limited effect upon recruitment and the profitability storyline was not institutionalized in recruitment policy.

The community coalition: regional development as the solution to the recruitment problem

The second storyline in the recruitment narrative is the community storyline. This storyline focuses on regional development and community values, particularly on the fishing industry's responsibility to provide regional employment. The storyline is closely attached to the local community paradigm (Figure 1), which considers fisheries and 
coastal communities to be mutually dependent for survival. Olsen (2011), a representative of the Socialist Party, embodied the spirit of this storyline when he said,

We need a fishery policy that will provide a living for the coastal communities. It is a paradox that Norway's fish stocks are at a maximum, while many fishing and coastal communities are down on their knees .... We demand a policy that takes into consideration communities that are dependent on fisheries.

Hence, the community coalition argues for maximum employment, within the limitation of the resources (Johnsen 2004). In terms of recruitment, the community storyline considers the increased price of quotas to be a structural hindrance for youth who would otherwise establish in the sector. The SQS "makes the quota expensive. For those who participate, [the business] becomes so costly that the descendants cannot take over" (Coastal fisher and vessel owner 15 2011). Proponents of this storyline thus believe that the SQS contribute to the demographic shifts in the fleet and the communities from young to old. They argue that political intervention is necessary in order to secure fleet recruitment and community survival. A typical community coalition statement is as follows:

Restructuring policies have reduced recruitment due to the high price of the quotas. The quota has a higher value than the vessel, and results in a price that is too high for those who want to establish. With the equity requirements of the banks, recruitment must decline (NCFA 2011a).

In this situation, recruitment is more than recruiting workers to the fleet. It is also recruiting citizens to coastal communities. According to the community coalition, the solution to the recruitment problem does not lie solely within market mechanisms, but also in political intervention, particularly political will and the courage to make changes (Kari 2011).

As profitability is also a priority for the community coalition, their priorities may not seem all that different from those of the profitability coalition. However, the community coalition argues for a profitable fleet in order to secure a sustainable local fishing fleet, local communities and regional development. According to the NCFA (2011b),

We all want the fisheries industry to be profitable. The [Conservative Party's] declaration about profitability is incomplete. It has to be followed by a clear message about who one wants to benefit from the values created. Erna Solberg from the Conservative Party is not thinking about the coastal population.

The community coalition includes small-scale fisheries interests such as the Norwegian Coastal Fishermen's Association (NCFA), the Sami Parliament, Sami interest organizations (including the Norwegian Sami Association and the Sami National Association), a number of social scientists, political parties such as the Socialist Party and the Centre Party, the Executive Committee for Northern Norway (LU), and fisheries-dependent municipalities. ${ }^{j}$

As with the profitability storyline, the community storyline has been around since WWII. However, it was not until the 1970s that the Local Community Paradigm's 
academic work began to actively focus upon the community aspect of the fishery recruitment (Barth 1966; Brox 1966; Hersoug 1983; Hersoug et al. 1993). Coastal employment and settlement then became central political objectives for fisheries. Community was seen as a venue for fleet recruitment, and the fleet a venue for community recruitment. However, despite increased community focus and a strong social actor, the fisheries authorities had more faith in Hardin's storyline when it was time to address resource challenges. Thus, when the Norwegian spring spawning herring stock collapsed in the late 1960s, the government chose to limit access and introduce concessions (Hersoug 2005).

Throughout the 1980s, the number of fishers continued to decline, and the fleet struggled with poor profitability. At the same time, the coastal communities struggled to maintain their population. Moreover, as a result of economic liberalization policies, the fisheries sector was relieved of some of its social responsibilities.

Secure jobs in the fisheries can in the long-run only be achieved by the industry itself, with foundation in the most profitable and efficient production possible. ... It must be stressed that the fishing industry can only partly contribute to maintaining the main settlement pattern (White Paper WP No. 93 1982-83, 8).

Hence, coastal employment and settlement changed from being a direct policy objective to an indirect objective. The community coalition moved into the background in the general fisheries policy debate, but continued to contribute to the recruitment debate, as traditional recruitment mechanisms were still recognized as important for fleet recruitment (Jentoft and Wadel 1984). The fact that these two contending storylines existed side by side has characterized the fisheries recruitment debate in Norway, until recently.

The developments in the 1990s, described above, also affected the community coalition. The NEA Cod Crisis in 1989 and 1990 forced large numbers of fishers to exit the fleet. Reduced quotas in the following years further exacerbated the problem, and even more fishers were left onshore, unemployment (Grytås 1990). In some communities, the number of enforced payments skyrocketed. ${ }^{k}$ The situation was felt at all levels in the coastal communities, as illustrated by the minister in Karlsøy, Troms:

The crisis affects individuals, and now affects so many that the whole community is shaken to its foundations .... The fishers here are proud people, accustomed to fend for themselves and live by what they are able to create with their own hands. Now we see them losing their self-respect. They feel that they are not worth anything because they have to resort to social security and are unable to keep the police off their doorsteps (Veigård 1990).

Traditional recruitment mechanisms were still present, but in the eyes of the community coalition, the NEA Cod Crisis significantly weakened these mechanisms. Low birth rates in the 1970s and 1980s made fewer recruits available, and increased formalization of the school system kept youth away from the fisheries, as the youths were no longer socialized into the fisheries (board member of the Sami National Association to Hamnvik 1994). ${ }^{1}$ Young people watching how fishers struggled financially 
became hesitant to enter the fisheries and increasingly sought work in other sectors, often outside their local communities. Moreover, low quotas and a decrease in vessels reduced the demand for crew, and youths had fewer opportunities to enter the fisheries (Alvheim 1998). In some communities, recruitment to the fisheries was so low that the lack of recruitment was perceived as a threat to the communities' existence (Seglsten 1994; Jensen 1996; Rein 1999).

Despite increased market orientation and decreased social responsibility, the fisheries political objectives continued to include community considerations in the 1990s. The fisheries policy was to "facilitate a profitable development of the fisheries sector .... Through market orientation and increased value creation, the sector [should] contribute to secure jobs and settlement along the coast" (White Paper WP No. 51 1997-98, 15). The continued presence of employment and settlement considerations in fisheries policy may be translated as a result of an influential community coalition. However, the main negotiating partner to the fisheries authorities in fisheries policy was the NFA, who was catering to both the offshore and the coastal fleet interests. Hence, it is more likely that it was an attempt to keep controversies to a minimum. Though, the presence of community oriented objectives may also be seen as the authorities' attempt to make fisheries policy palatable for community coalition actors. Even so, the controversies in 1990 were so great that a number of the coastal fishers left the NFA and established the Norwegian Coastal Fishermen's Association (NCFA 2012).

The declining number of fishers continued into the new millennium, and the community coalition did not welcome the quota systems introduced in 2000 and 2003. They expected the SQS to "gather fishing rights into a few hands" and thus negatively affect community economies. The coalition raged against the SQS and demanded its withdrawal (Johansen 2002; Jakobsen and Horn 2004). The government was accused of catering to large-scale fishing operations to the point where small-scale adjustments became unprofitable, which lead to job losses in the community (Nygarrd 2003). The community coalition also expected SQS to further deter youth from entering the fishery or putting heavy debt burdens upon those who did, because of increased quota prices (Green Paper NOU 2006:16). They argued that vessels under fifteen meters in length, being the most labour intensive segment of the fleet, had to be shielded from further downscaling of their operations. The negative effects of the SQS upon communities and recruitment were problematized by a Northern Norwegian newspaper as follows:

When it comes to restructuring, it is good business for those who buy rights and then sell them for a big personal gain, at the expense of the community.

Communities are being drained .... But I also see the other side of restructuring. Young people are leaving the boat. Restructuring has led to such large debts and such large quotas that crews are never able to take time off, which puts an inhuman strain upon crew members (Anon 2006).

Various local politicians in the Conservative Party (CP), the Coastal Party, and the Centre Party were also sceptical to the effects of the SQS (Anon 2005; Vestå and Sundheim 2006). It should particularly be noted that the CP Mayor in Hammerfest, 
Finnmark, opposed his own party on this issue (Conservative Party CP 2007), as he aligned himself with the community coalition:

I am sceptical to the application of the SQS to the fleet under 15 meters. Fishing rights may become too expensive. I worry about the consequences this may have for recruitment; we have to be careful not to unleash a system in which the small-scale fishers in the fjords feel unjustly treated (Jakobsen to Anon 2005).

But there was still hope that the community coalition could influence general fisheries policies. In 2005, the new Minister of Fisheries (Pedersen, LP) was enrolled in the community coalition, as she announced that her fisheries policies would "put lights in the houses" along the coast (Aslaksen 2011). This assertion indicated a break from the previous CP government's policy, and a focus on rationalization and downscaling. Her policy would allow more people to live of coastal resources. Great expectations were born as Pedersen froze the SQS in order to evaluate the system (Green Paper NOU 2006:16). However, the evaluation favoured a continuance of the SQS and concluded that Norway at large did not experience any negative socio-economic effects from it, although some municipalities could expect adjustment problems, such as short-run labour market problems and longrun changes in settlement. Rather than dismissing the SQS, as some community oriented actors had hoped, the government continued the SQS and expanded it to include vessels down to eleven meters in length. The community coalition had lost a player in the Minister of Fisheries and, worse, the community storyline was further marginalized as the profitability storyline was further locked into the regulation mechanisms.

Yet another attempt to re-establish the community coalition at the negotiating table came through the ethnic turn in the fisheries policy debate. This was an attempt to reintroduce fisheries as carriers of rural development, community, and culture. Since 2005, ethnic and local rights had gained room in resource management debates. An independent commission evaluated saltwater fishing rights in Finnmark in 2008. ${ }^{\mathrm{m}}$ The evaluation concluded that people living in the fjords and along the coast of Finnmark had legal and historical rights to fish off the coast of Finnmark (Green Paper NOU 2008:5). The document introduced rationalities other than purely economic ones: those related to rural development, culture, and community. Moreover, recruitment was a central issue in the evaluation. The evaluation argued that local fishing rights would allow small-scale fishers to continue fishing and thereby secure local employment, settlement, and fleet recruitment. Many community coalition actors, including Sami interests and small-scale fishers, saw the result of the evaluation as helping to create "a new era for the coast" (Gustavsen 2011). Other actors, such as the NFA, saw the document as a threat (Ballari 2008).

In spite of the conclusions of the evaluation, the government rejected historical fishing rights, and the Minister of Fisheries allotted only a statutory right of 3,000 tons coastal cod annually to fjord fishers. Some felt that the quota could give new impetus to people in small coastal communities, as it would allow them to buy vessels with quotas and thereby improve fleet recruitment (Aslaksen 2011). Others, however, felt betrayed by the Minister: one representative in the evaluation committee said, "This is betrayal of people. I am almost offended with regards to the thorough work the commission did" (Schanche 2011).

Local recruitment through social networks fended off the worst challenges of crew recruitment in the new millennium. However, given a lack of crew, coastal vessel 
owners either resorted to skipper-fishing or to foreign labour (Coastal vessel owner 4 2010; Johnsen and Vik 2008), in part because of the lack of interested coastal youth. ${ }^{\text {n }}$ As one a vessel owner in the smallest coastal fleet complained, "My son is taking over the fishing business, but the problem is that he has nobody to fish with. The youth here do not want to participate. Recruitment is destroyed. [There are] no youth left in the milieu" (Coastal vessel owner 12 2011). According to one Coastal fisher 27 (2012), "The ambitions are there, but it is difficult to get in". "The quotas are too expensive and cause a recruitment problem" (Coastal vessel owner 16 2011).

Although authorities argue that there is only a limited recruitment problem (MFCA 2008, 51), from the community coalition's point of view, recruitment of vessel owners is the biggest future challenge (Innst.S.nr. 238 2006-2007). According to the community coalition restructuring is the main reason for the recruitment problem (Coastal vessel owner 12 2011). As the NCFA (2011c) stated,

Restructuring has a number of adverse consequences. For the next generation, the quota price becomes an enormous barrier to entry. There is no reason to create a system that makes the quota owners millionaires from the trade of a commodity they do not own and that they received for free. The Coastal Fishermen's Association welcomes the suggestion of free fishing with passive gear for vessels under 15 meters. This will remove the interest in buying and selling quotas and give the young people a chance to become fishers.

Opponents might argue that poor recruitment is mitigated by modernization and restructuring. But from a community coalition point of view, modernization and restructuring may also be contributing to the recruitment problem. Fewer vessels and higher efficiency leave less room for youth to be socialized into the fisheries (Aune 2009). Moreover, fewer local vessels reduce local employment and leaves communities vulnerable. Hence, the community coalition believes there is a structural synergy between fisheries and communities, in which recruitment plays a central role.

In terms of general fisheries policy, the community coalition has not been structuralized or institutionalized. The coalition often argues for open access fishing with passive gear for the smallest boats in the fleet, in order to maintain local fishing activity. This has not been implemented, and it might never be. Rather, an increasing number of fisheries have been closed and the number of fishers has continuously declined (Hersoug 2005). Another example of the losing battle in general fisheries policies is the rejection of the regional fishing rights in Finnmark. Thus, the weaker position of the community coalition is due to its inability to enrol enough weighty actors into its network to assert its definition of the recruitment phenomenon (Næss 2003).

Despite its weakening position in general fisheries policies, the community coalition still carries some weight in the recruitment policy debate, as the current recruitment scheme is mainly about the implementation of recruitment quotas (Prop. 1 S 2009-2010; DoF 2012b). Supporters of the community coalition argued for recruitment quotas thusly: ${ }^{\circ}$

A large number of vessels and people are gone, but one can expect a normal situation where it will be more difficult to get crew. To address this potential problem, one should use recruitment quotas. Then, an extra person on-board 
[a recruit] would not "feed on" the share of those already hired, and one would avoid conflicts among crew members (Coastal vessel owner 3 2010).

Establishment grants were rejected on the grounds that they would easily be absorbed by the market prices and further capitalise the fleet and increase the entry price. Hence, implementing recruitment quotas was the preferred method, as these would avoid further capitalization and allow youth to enter without taking on large debts (NCFA 2008). As recruitment quotas were implemented, the community storyline has, to some extent, been institutionalized (Hajer 2012). However, this measure is only temporary. It remains to be seen whether the institutionalization of the community storyline continues.

In terms of structuration, the storyline of the community coalition has not convinced the majority of the fisheries actors. Moreover, the community coalition has often been discredited; proponents of this coalition have been referred to as "small-scale romantics," outdated and archaic (Lorentzen 2004; Sagat 2012). For example, an editorial in a fisheries industry magazine stated,

To those who claim that restructuring policies ... will not make the coastal fleet more profitable, we have the following comment: it is nonsense! Of course profitability will improve. Ask all the fishing vessel owners that will make use of the system. The opposite argument, made by Ottar Brox and a number of researchers and teachers at the Norwegian College of Fishery Science, is-in our eyesridiculous (Norsk fiskerinæring 2002).

\section{The pragmatic-fisher storyline: no universal solution to the recruitment problem}

As outlined in Figure 1, polarization and paradoxes in fisheries politics and management is probably more the norm than the exception. The storylines discussed so far are tied to historic and academic descriptions of recruitment. To some degree, these storylines have been polished and rehearsed for the public discourse. But whether or not these storylines are valid in daily fishing practices is another issue. This is why Ostrom (1990) is concerned with the realism of narratives and storylines in relation to real-life context and policy making. And this is where the third storyline, to be developed in this section, appears.

Before exploring the third storyline, one point needs to be made regarding the method. One characteristic of grounded theory design, and ANT, is that categories are developed from data during the research process, and not predefined from theory. Categories have not been tested against a larger material, but the lack of predefined categories is also an advantage, as it allows storylines to emerge. This is where ANT proved useful and resulted in a third storyline: the pragmatic-fisher storyline.

The pragmatic-fisher storyline supports the pragmatic-fisher coalition, which consists mainly of active fishers from all fleet segments, and actors close to the practical fishing activity. The pragmatic-fisher storyline differs from the profitability and the community storylines in that the two latter are discursive formations positioned within an ideological-political field. However, among those who conduct daily fishing activities the boundaries between the storylines break down. Hence, a new storyline emerges, which is positioned between the two and which uses repertoires from both ideological storylines (see Figure 2 below). 


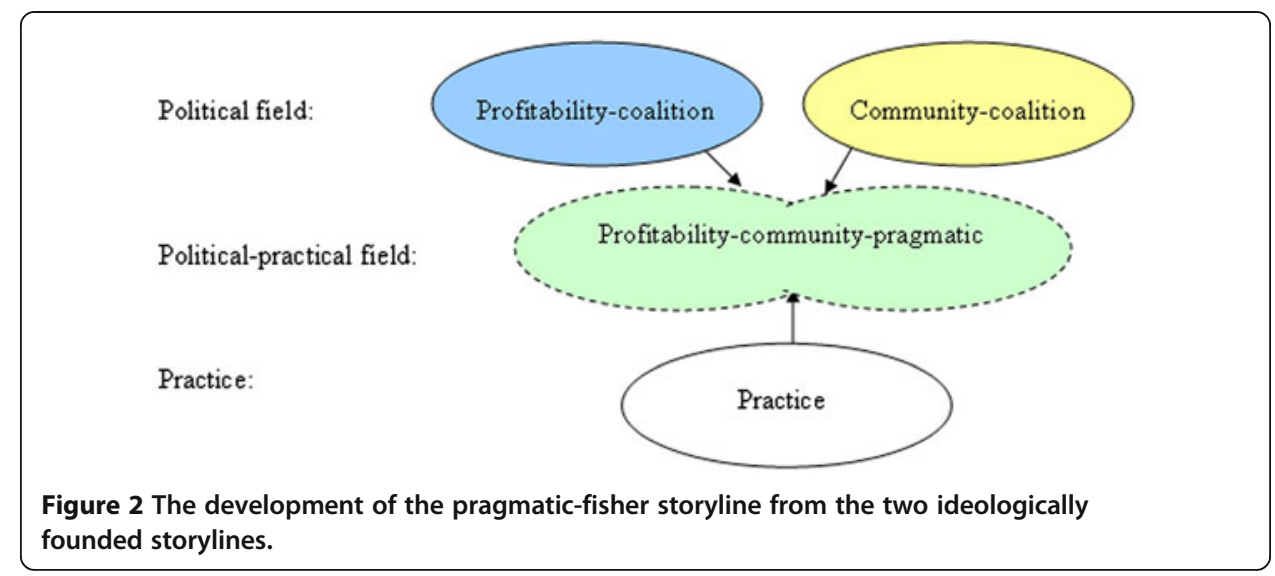

Thus, the pragmatic-fisher storyline materializes in-between and across ideologies. For instance, a small-scale vessel owner, whose arguments mostly fall within the community storyline, makes use of the profitability storyline when discussing restructuring policies: "[Restructuring] has made [fishing] more stable and improved income. It has made work more comfortable. Everything was not better before. Things change and one has to hang in there. But that is what makes it fun" (Coastal vessel owner 7 2010). This is also evident when a large-scale offshore vessel owner whose statements mainly fall under the profitability storyline uses the community storyline when he claims, "I do not believe that further restructuring will solve the profitability problem. It will only lead to more debt" (Offshore vessel owner 17 2011).

Informants also combine repertoires from the two ideological storylines. Using the community storyline, informants make statements such as, "Tradable quotas lead to recruitment problems," while in the next sentence claiming, "Profitability has to improve to increase recruitment" (Coastal vessel owner 28 2011). Or, as an older coastal fisher said in relation to fleet restructuring: "[Restructuring leads to] fewer fishers. That is no good. But at the same time it is what allows some fishers make money" (Coastal vessel owner 12 2011).

The pragmatic-fisher storyline is also characterized by being a product of the divergence between recruitment discourse and practice. The profitability and the community storylines are positioned in a political landscape, while the pragmatic-fisher storyline is located in a practical landscape (Figure 2). The ideologically founded storylines adapt in the meeting with a complex reality and practice adapts to discourse.

For example, a number of informants in the small-scale fleet publicly opposed restructuring policies, but had adapted to the new realities and regulations and were also actively making use of the restructuring scheme. One informant, who was actively involved in local politics and openly voiced his opposition to the restructuring policies, pointed to this divergence and how fishers can feel torn between their values and actual practice:

Fleet restructuring has led to a doubling of the debt, but we are left with the same amount of fish. The fisheries have become more predictable, but we should discuss how we achieved this. A number of vessels with crew have utilized the restructuring scheme. Not all are positive to it, but simply have to hang in there. The world moves on (Coastal vessel owner 3 2010). 
Beyond the primary distinction, described above, the pragmatic-fisher storyline has several other characteristics that set it apart from the profitability and community storylines. For example, informants also applied different storylines with different logics to different settings. Informants recognized that fleet restructuring has improved income and predictability in the fishery, but they also asserted that restructuring should not be applied equally across the fleet. Hence, one Coastal vessel owner 18 (2011) stated, "Restructuring over eleven meters is OK . . ., but below eleven meters: No!" A younger, small-scale vessel owner also illustrated this pattern of argumentation when asked about restructuring policies:

Obviously, [fishing] has become more predictable. [Restructuring] is a necessity for big boats, but not for the small ones. That would make the entry price too high. Presently, there are good opportunities in the fleet below eleven meters (Coastal vessel owner 8 2010).

Another important characteristic of the pragmatic-fisher storyline is that it is dynamic in time and space. That is, its discursive practices change over time, thus allowing statements that might have been unacceptable in the past to become acceptable at a later point in time (Schaaning 1997). For instance, following the collapse of the NEA cod in 1990, the introduction of limited fishing rights was not welcomed and was intended to be a temporary measure. Five years later, the NFA had changed position and sought to make the system permanent. This change of heart might have been the result of the fishers discovering the benefits of reduced participation and that the fishing right had become valuable (Hersoug n.d.). Hence, statements and opinions changed as policy and opportunities changed.

As the pragmatic-fisher storyline does not follow an ideology as clear-cut as the other two storylines, its degree of domination is somewhat more difficult to gauge. However, whereas the profitability and community storylines dominate discursively, the pragmaticfisher storyline dominates in practice. In general, fisheries policies realize the pragmaticfisher storyline by implementing restructuring policies that vary across the fleet and exempt segments of the fleet (below eleven meters in length). In recruitment policy, the pragmatist storyline is evident in that ideas from both the profitability and the community storylines are applied practically through establishment grants and recruitment quotas.

\section{Storylines, policies, and practices: divergences}

The majority of fishery actors, whether academics or policy makers, tend to work within a discourse. However, there is no need to be restrained by a discourse. One purpose of this article is to simply point out that there may be alternatives to present policies. This is not only a liberating exercise (Hidding et al. 2000), but also makes us aware that policy rhetoric and practices are not a given, nor are they always synchronized.

The Norwegian recruitment debate has utilized the recruitment discourse to construct: 1) recruitment problems as a result of poor fleet profitability or 2) recruitment problems as a result of restructuring policies. The first tied to the profitability storyline and the second to the community storyline. This particular finding may not add much new knowledge. The identification of the third storyline-the pragmatic-fisher storyline-is the true discovery. 
For the profitability coalition, recruitment is an input in the production chain. The profitability coalition assumes that successful recruitment can be secured by further limiting participation. For the community coalition, recruitment is also about community survival and satisfactory coastal lives (Jentoft 1984; Skjærvik 2009; Troms folkeblad 2010); thus, successful recruitment is assumed to be a result of increased participation. This is the source of the paradox: based on political ideology, the solution in one perspective is the root of the problem in the other (indicated by red arrows in Figure 3). Within this paradox is where the pragmatic-fisher storyline forms.

But the divergence is not only related to a divergence between two ideologies, as stated above, there is also a divergence between discourse and practice. Currently, the profitability and the community coalitions offer a limited set of solutions to the recruitment problem: either establishment grants or recruitment quotas. In practice, however, a bit of both were used. The result is contradicting recruitment measures (Næss 2003). As fleet recruitment is a highly politicized field, the authorities seem to choose a rather pragmatic line in order to keep the controversies to a minimum, and the recruitment issue remains unsolved.

The SQS has been the main solution used in Norwegian fisheries policy since the turn of the millennium. It has been efficient in terms of improving fleet profitability (DoF 2012a), but has not been able to solve social problems to the same extent. Individual vessel owners acting rationally are continuously pushing for further restructuring (Offshore vessel owner 18 2012; Norweigan Fishermen's Association NFA 2012). In terms of fleet profitability and solving short-run recruitment problems, further restructuring may be a sensible action. Further restructuring and closing of fisheries could improve income opportunities for those who are involved, thus making fishery activities more attractive, albeit more difficult to enter. Thus, some fishing communities may experience growth as the result of further restructuring, as they are able to obtain fishing rights and quotas. However, from a long-run, rural development perspective, further restructuring may cause a deterioration and disintegration of employment systems in some communities (Johnsen and Vik 2013).

From a profitability coalition's point of view, the lack of interested youth may be accommodated by the use of foreign labour. This would require a recruitment policy increasingly focused on instrumental recruitment. However, the use of temporary foreign labour may cause a recruitment-vacuum, in which the pool of Norwegian crew members potentially advancing to vessel owners or skippers grows smaller, thereby inhibiting satisfactory recruitment to these positions (Coastal vessel owner 24 2012; Coastal vessel owner 25 2012). As the fleet's success still depends upon informal knowledge transferred between generations, the use of foreign labour may contribute to the loss of specialized, often local, knowledge. One coastal vessel owner using temporary foreign labour stated, "The foreigners are here to stay and I have good experiences with them .... But training takes a lot of time and one will never be able to make as good a fisher out of a foreigner as out of a Norwegian" (Coastal vessel owner 26 2012). What the vessel owner is pointing to is not necessarily that foreign workers are inferior to Norwegians, but rather that Norwegians acquire essential informal and local knowledge thorough informal socialization. In other words, increasing foreign labour to solve profitability and recruitment problems may create a knowledge problem. This does not mean that we should not solve the profitability challenge-after all, fishers have to 


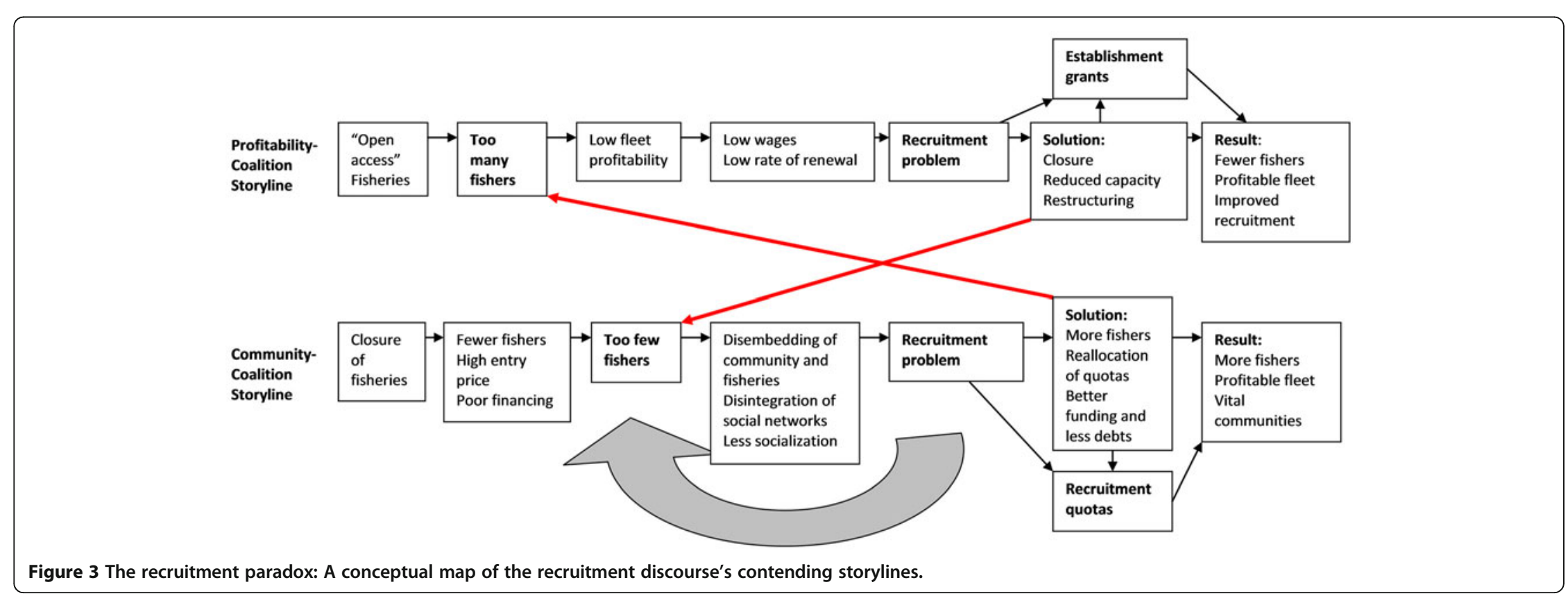


make money. But we have to recognize that a singular profitability focus has long-term consequences.

In order to deal with the recruitment paradox, we must consider alternative solutions. However, the institutional arrangements and organizational practices managed by bureaucracy are increasingly following the profitability ideology of further restructuring. Fisheries policies are therefore increasingly locked in predefined bureaucratic systems, like the SQS, and power is transferred from politicians to bureaucrats. Hence, fisheries politics might have become rigid and depoliticized. We may question whether we have come to a point of no return.

In practice, fishers are adaptive and will continue to alter their discursive and fishing practices to meet shifting frame conditions. The discourse is also likely to adapt to changing practices. Rather than having two diverging storylines, the future discourse may converge towards a single pragmatic storyline that picks arguments from different ideologies depending upon the circumstances. A good fishery policy has to balance many considerations, and thus we need a policy where the skipper has his hands on the wheel; we cannot rely on auto-pilot politics. Hence, the solution may not lie in blind ideology. We should not limit ourselves to a particular discourse, which would only narrow our options. As the world is complex and dynamic, and as there is likely to always be a paradox, recruitment policies must be pragmatic and pliable; they must consider the different characteristics and demands of the various aspects of the fishing fleet.

\section{Towards a more pragmatic recruitment policy?}

This article identifies three storylines within the recruitment discourse: the profitability storyline, the community storyline, and the pragmatic-fisher storyline. It has shown how the first two storylines developed, how they have contributed to keeping the coalitions together, and how the negotiating power of the different coalitions has changed over time. As no storyline is dominant in the recruitment discourse, and because there is divergence between storylines, as well as between discourse and practice, a recruitment paradox occurs. Hence, in practice, the result is a pragmatic recruitment policy, with recruitment measures based in two different ideologies. The result is contradicting recruitment measures: some limiting participation while others increase participation. Hence, the result is incoherent recruitment policies and poorly defined policy objectives.

The storylines are founded in different ideologies. Unfortunately, policies that are heavily based on ideology lock policies into narrow courses of action, and provide only a limited set of available solutions. In a complex reality, wherein processes continually produce knowledge, the images or storylines upon which we build policies will have to be revised. Besides, fishers are pragmatic and do not act within a particular ideology, but act in relation to the world around them. Rather than a policy defined by a small, ideological tool box, we have to accept the presence of a paradox and realize that the solution may have to have a more pragmatic approach. We must truly define the problem before taking action. In addition, good governance implies that systems are responsive. We need to recognize that policy is multiple and composite, and that strategies and actions have to be applied to the appropriate challenges. If recruitment problems are caused by poor profitability, then fleet restructuring and rationalization may be the answer. If the recruitment problem is due to the lack of available recruits in the local community, restructuring may only aggravate the problem. Simultaneously, there has 
to be a trade-off between predictability and possibility, in order to adjust the course of action as necessary.

In the long-run, perhaps we have to accept continued downscaling of the fisheries in some regions or within some fleet segments. Perhaps we will even lose some fisherydependent communities. This downscaling of fisheries activities can only be justified if it does not destroy long-run recruitment of skilled, knowledgeable fishers to the fleet. Recruitment policy has been the case of this article, but the points made here are also important for general fisheries policy. As we work towards specific goals, we have to be aware that each solution has consequences.

\section{Notes}

a Recruitment is also a direct translation from the Norwegian rekruttering.

b Although Hardin defined a specific context for his actors, solutions to avoid collective ruin has been translated into limited access, quota programs, and rights allocations in Norway, as well as in other Western, industrial fisheries (Ostrom 1990; Jentoft et al. 2010).

${ }^{c}$ The counties of Troms, Møre and Romsdal, and Sogn and Fjordane.

d The Main Agreement (1964) was a frame agreement between the state and the fisheries regarding annual transfer payments (subsidies) to secure income and living conditions for the fishers and their families.

e The unit quota system divides the annual total allowable catch by the number of vessels and allocates an equal portion to each vessel over twenty eight meters.

${ }^{\mathrm{f}}$ The SQS allows two vessels within the same fleet category to merge quotas onto one vessel, given that one vessel withdraws from commercial fishing. This was initially applicable to vessels over fifteen meters.

${ }^{\mathrm{g}}$ The subsidies were net-wage pay (nettolønnsordning), which a system in which employers in the maritime sectors receive a tax refund for the taxes paid by the seamen. It is used to keep Norwegians on Norwegian ships that are competing with foreign shipping companies with cheaper labour.

${ }^{\mathrm{h}}$ Prior to 2010, through regulations the maximum size of a coastal vessel was twenty eight meters in length. In 2010, this changed to 500 cubic meters, thus increasing the demand for certified labour.

${ }^{\mathrm{i}}$ Establishing as a vessel owners in the offshore fleet and on large coastal vessels is a great financial challenge. Large amount of money is needed and is beyond the scope of this article.

j Steigen, Moskenes, Balsfjord, Øksnes, Kåfjord, and Værøy.

${ }^{\mathrm{k}}$ Tvangsinndrivelse.

${ }^{1}$ A reform in the senior secondary school system granted all youth twelve years of schooling.

${ }^{m}$ A law was passed dealing with the rights to terrestrial and inland aquatic areas and resources in Finnmark, the northernmost county in Norway (Lov 17. juni 2005 nr. 85 om rettsforhold og forvaltning av grunn og naturresurser i Finnmark Fylke ["Finnmarksloven"], [c.f. $\$ 1]$ ).

${ }^{\mathrm{n}}$ Skipper-fishing is when skippers work as crew on each other's boats and thereby reduce demand for crew.

${ }^{\circ}$ The recruitment quota this fisher is arguing for is slightly different from those actually implemented, as the implemented recruitment quotas were allocated to young vessel owners, not to a crew member. 


\section{Abbreviations}

ANT: Actor-network theory; CP: Conservative party; DA: Discourse analysis; DoF: Directorate of fisheries;

FVOA: Norwegian fishing vessel owner association; LP: Labour party; LU: Executive committee for northern norway (Landsdelsutvalget); MA: Main agreement; MFCA: Ministry of fisheries and coastal affairs; NCFA: Norwegian coastal fishermen's association; NEA: North east arctic; NFA: Norwegian fishermen's association; NOU: Green paper; WP: White paper; WWF: World wildlife foundation; WWII: World War II; SQS: Structure quota system.

\section{Competing interests}

The authors declare that they have no competing interests.

\section{Acknowledgements}

I would like to thank the Norwegian Research Council and the Fishery and Aquaculture Industry Research Fund for funding my research and my PhD work. I would also like to thank my two supervisors, Jahn Petter Johnsen and Jostein Vik, for their valuable comments and guidance.

\section{Received: 24 April 2013 Accepted: 25 April 2013}

Published: 20 August 2013

\section{References}

Alvheim, S. 1998. En felles fremtid. .. ? En analyse av muligheter, begrensninger og utfordringer for en bærekraftig næringsutvikling i det fiskeriavhengige lokalsamfunnet Kjøllefjord i Lebesby Kommune. [Norwegian]. Bergen: Insitutt for geografi.

Anon. 2005. Må finne overgangsordninger, Norwegian. Bergen: FiskeribladetFiskaren. 24.09.2005.

Anon. 2006. Åpent brev til fiskeriminister Helga Pedersen, Norwegian. Tromsø: Bladet Tromsø. 31.05.2006.

Apostle, R, BJ McCay, and KH Mikalsen. 2002. Enclosing the Commons: Individual Transferable Quotas in the Nova Scotia Fishery. St. Johns, Nfld: iser Books.

Aslaksen, E. 2011. Finnmark: Går i land og flytter, Norwegian. Oslo: NRK. Accessed: 30.01.2012. http://m.nrk.no/m/artikkel. jsp?art_id $=17645568$.

Aune, J. 2009. Færre og gamlere fiskere, Norwegian. Andenes: Andøyposten. 29.01.2009.

Ballari, A. 2008. Full splittelse av fiskeri-Norge, Norwegian. Oslo: NRK. Accessed: 18.03.2011. http://www.nrk.no/nyheter/ distrikt/troms_og_finnmark/1.4858788.

Barth, F. 1966. Betydningen av transaksjoner som analytisk begrep. In Fiske og lokalsamfunn, Norwegian, ed. IL Høst and C Wadel, 26-42. Oslo: Universitetsforlaget.

Biernacki, P, and D Waldorf. 1981. Snowball sampling—Problems and techniques of chain referral sampling. Sociological Methods and Research 10(2): 141-163.

Bingham, A. 2010. Discourse of the dammed: A study of the impacts of sustainable development discourse on indigenous peoples in the Brazilian Amazon in the context of the proposed Belo Monte hydroelectric dam. POLIS Journal 4: 1-47.

Brox, O. 1966. Hva Skjer I Nord-Norge. Oslo: Pax.

Caddy, JF, and KL Cochrane. 2001. A Review of Fisheries Management Past and Present and Some Future Perspectives for the Third Millennium. Ocean \& Coastal Management 44(9-10): 653-682.

Chief of Crew 1. 2012. Personal Communication.

Coastal fisher 27. 2012. Personal Communication.

Coastal fisher and vessel owner 15. 2011. Personal Communication.

Coastal vessel owner 12. 2011. Personal Communication.

Coastal vessel owner 16. 2011. Personal Communication.

Coastal vessel owner 18. 2011. Personal Communication.

Coastal vessel owner 24. 2012. Personal Communication.

Coastal vessel owner 25. 2012. Personal Communication.

Coastal vessel owner 26. 2012. Personal Communication.

Coastal vessel owner 28. 2011. Personal Communication.

Coastal vessel owner 3. 2010. Personal Communication.

Coastal vessel owner 4. 2010. Personal Communication.

Coastal vessel owner 7. 2010. Personal Communication.

Coastal vessel owner 8. 2010. Personal Communication.

Conservative Party (CP). 2007. Minutes from Parliamentary committee meeting Tuesday 5.6.2010, Norwegian. Oslo: Norwegian Parliament.

Directorat of Fisheries (DoF). 2006. Hearing—NOU 2006:16—Strukturvirkemidler i fiskeflåten, Norwegian. Oslo: Ministry of Fisheries and Coastal Affairs.

Directorate of Fisheries (DoF). 2008a. Helhetlig forvaltningsplan for Norskehavet-Konsekvenser av fiskeriaktivitet, Norwegian. Bergen: DoF.

Directorate of Fisheries (DoF). 2008b. Høringsuttalelse om rekruttering i fiskeflåten_Etablering som fartøyeier, Norwegian. Oslo: Ministry of Fisheries and Coastal Affairs.

Directorate of Fisheries (DoF). 2011. Kraftig økning av fiskebestander, Norwegian. Oslo: DoF. Accessed 02.05.2012. http://www.fiskeridir.no/fiske-og-fangst/aktuelt/2011/0511/kraftig-oekning-av-fiskebestander.

Directorate of Fisheries (DoF). 2012a. Lønnsomhetsundersøkelsen 2010 (Profitability survey on the Norwegian fishing fleet 2010), Norwegian. Bergen: Directorate of Fisheries.

Directorate of Fisheries (DoF). 2012b. Personal Communication with advisor at DoF.

Fishing Vessel Owners' Association (FVOA). 2006. Hearing-NOU 2006:16-Strukturvirkemidler i fiskeflåten, Norwegian. Oslo: Ministry of Fisheries and Coastal Affairs. 
Fishing Vessel Owners' Association (FVOA). 2011. Årsrapport Fiskebåtredernes forbund, Norwegian. Ålesund: Fiskebåtredernes forbund.

Gordon, HS. 1954. The economic theory of a common-property resource: The fishery. J Polit Econ 62(2): 124-142. Green Paper NOU. 2006:16. Strukturvirkemidler i fiskeflåten. Ministry of Fisheries and Coastal Affairs: [Norwegian]. Oslo. Green Paper NOU. 2008:5. Retten til fiske i havet utenfor Finnmark. [Norwegian]. Oslo: Ministry of Fisheries and Coastal Affairs. Grytås, G. 1990. Fiskere sparkes, Norwegian, 24.02.1990. Tromsø: Nordlys.

Gustavsen, J. 2011. Et tidsskille for kysten, Norwegian. Kautokeino: Galdu. Accessed 05.05.2012. http://www.galdu.org/ web/index.php?odas=5170\&giella1 $=$ nor\#.

Hajer, MA. 1995. The politics of environmental discourse: Ecological modernization and the policy process. Oxford: Oxford University Press.

Hajer, M. 2012. http://www.maartenhajer.nl/wordpress/. Wordpress. Accessed 06.06.2012.

Hajer, M, and W Versteeg. 2005. A decade of discourse analysis of environmental politics: achievements, challenges, perspectives. Journal of Environmental Policy \& Planning 7(3): 175-184.

Hamnvik, S. 1994. Distriktene avfolkes, Norwegian. Tromsø: Nordlys. 02.11.1994.

Hannesson, R. 2005. Fiskerettigheter og ressursrente-SNF Rapport 05/05, Norwegian. Bergen: SNF.

Hardin, G. 1968. The tragedy of the commons. Science 162(3859): 1243-1248.

Hersoug, B. 1983. Fiskeriplanlegging—Offentlig styring eller politisk pliktøvelse. In Kan Fiskerinæringa Styres? Norwegian, ed. B Hersoug, 17-78. Oslo: NOVUS.

Hersoug, B. 2005. Closing the commons-Norwegian fisheries from open access to private property. Netherlands: Eburon.

Hersoug, B. n.d.. Distriktspolitiske utfordringer i flåteleddet. Vedlegg til distriktskommisjonen. Oslo: Ministry of Local Government and Regional Development. Accessed: 05.09.2012. http://www.regjeringen.no/Upload/KRD/Vedlegg/ REGA/distriktskommisjonen/18.Hersoug.pdf.

Hersoug, B, and P Arbo. 1997. The globalization of the fishing industry and the case of Finnmark. Marine Policy 21(2): 121-142.

Hersoug, B, P Holm, and A Maurstad. 1993. Fra økonomisk rasjonalitet til økologisk fornuft. [Norwegian]. Tidsskrift for Samfunnsforsking 34(2): 101-125.

Hersoug, B, P Holm, and SA Rånes. 2000. The missing T. path dependency within an individual vessel quota systemThe case of Norwegian cod fisheries. Marine Policy 24: 319-330.

Hewitt, S. 2009. Discourse analysis and public policy research. Centre for Rural Economy Discussion Paper Series No. 24. Newcastle: Newcastle University.

Hidding, M, B Needham, and J Wisserhof. 2000. Discourses of town and country. Landscape and Urban Planning 48: 121-130. Holm, P. 1995. The dynamics of institutionalization; Transformation processes in Norwegian fisheries. Adm Sci Q 40: 398-422. Holm, P. 1996. Kan torsken temmes. In Det nye Nord-Norge. Avhengighet og modernisering i nord, Norwegian, ed. OE Eriksen, 109-142. Bergen-Sandviken: Fagbokforlaget.

Holm, P. 2001. The Invisible Revolution: The Construction of Institutional Change in the Fisheries. Doctoral dissertation. Tromsø: Norwegian College of Fishery Science, University of Troms $\varnothing$.

Holm, P, and JP Johnsen. 1990. Hovedavtalen for Fiskerinæringa ved en Norsk EF tilpasning, Norwegian. Trondheim: Fiskernes EF-utvalg, Norges Fiskarlag.

Holm, P, and KN Nielsen. 2007. Framing fish, making markets: The construction of individual transferable quotas (ITQS). Sociol Rev 55(2): 173-195.

Innsl.S.nr. 271. 2002-2003. Innstilling Fra Næringskomiteen om Strukturtiltak i Kystfiskeflåten, Norwegian. Oslo: Ministry of Fisheries. Innst.S.nr. 238. 2006-2007. Innstilling Fra Næringskomiteen om Strukturpolitikk for Fiskeflăten, Norwegian. Oslo: Næringskomiteen.

Jakobsen, R, and KS Horn. 2004. Finnmark har fisk nok, Norwegian. Oslo: NRK. Accessed 12.03.2012. http://www.nrk.no/ nyheter/distrikt/nrk_troms_og_finnmark/finnmark/4282718.html.

Jensen, HW. 1996. Orker ikke mer, Norwegian. Oslo: Verdens Gang. 03.05.1996.

Jentoft, S. 1984. Hvor sårbare er fiskerimiljøene? In I samme båt - sysselsettingssystem i fiskerinæringa, Norwegian, ed. S Jentoft and C Wadel. Drammen: Universitetsforlaget

Jentoft, S, and C Wadel. 1984. I Samme Båt_-Sysselsetningssystem i fiskernæringa, Norwegian. Drammen: Universitetsforlaget.

Jentoft, S, BJ McCay, and DC Wilson. 1998. Social theory and fisheries co-management. Marine Policy 22: 423-436.

Jentoft, S, R Chuenpagdee, A Bundy, and R Mahon. 2010. Pyramids and roses: Alternative images for the governance of fisheries systems. Marine Policy 34: 1315-1321.

Johansen, EM. 2002. Vi Er Enda Sterkere Nå Norge, Norwegian. Tromsø: Nordlys. 13.08.2002.

Johnsen, JP. 2004. Fiskeren som forsvant? Avfolking, overbefolking og endringsprosesser i norsk fiskerinæring i Et AktørNettverk-Perspektiv, Norwegian. Trondheim: Tapir akademisk forlag.

Johnsen, JP, and J Vik. 2008. Mellom marked og nettverk: om fiskerirekruttering og sysselsettingssystemer i fiske, Norwegian Trondheim: Bygdeforsking.

Johnsen, JP, and J Vik. 2013. Pushed or pulled? Understanding fishery exit in a welfare society context. MAST 12(4): 1-20.

Kari, K. 2011. Tapte Jussen, Vinner Politikken. In Østbloggen, Norwegian. Vadsø: Finnmarken. Accessed: 12.09.2012. http://stbloggen.origo.no/-/bulletin/print/649206_tapte-jussen-vinner-politikken.

Kooiman, J. 2003. Governing as governance. London: Sage.

Kyst og fjord. 2011. Blir færre og eldre, Norwegian. Kjøllefjord: Kyst og Fjord. Accessed 25.05.2011. http://www. kystogfjord.no/nyheter/forsiden/Blir-faerre-og-eldre.

Latour, B. 2005. Reassembling the social—An introduction to actor-network-theory. New York: Oxford Univeristy Press Lorentzen, J. 2004. La kysten leve, Norwegian. Hasvik: Måsegget.

Maurstad, A. 2000. To fish or not to fish: Small-scale fishing and changing regulations of the cod fishery in Northern Norway. Hum Organ 59(1): 37

McCay, BJ. 1999. That's Not Right': Resistance to Enclosure in a Newfoundland Crab Fishery. Fishing Places, Fishing People. In Traditions and Issues in Canadian Small-Scale Fisheries, ed. D Newell and R Ommer, 301-318. Toronto: University of Toronto. 
McGoodwin, JR. 1990. Crisis in the world's fisheries. CA: Stanford University Press.

Merriam-Webster Online. 2012. http://www.merriam-webster.com/. Accessed 24th of March 2012.

Ministry of Fisheries and Coastal Affairs (MCFA). 2008. Rekruttering i fiskeflaten-Etablering som fartøyeier. Oslo: Ministry of Fisheries and Coastal Affairs.

Ministry of Fisheries and Coastal Affairs (MFCA). 2006. Fra ungdom til fisker, fra fisker til fartøyeier-Rekrutterings- og etableringsordninger for ungdom til fiskefläten. Oslo: Ministry of Fisheries and Coastal Affairs.

Momyr, M. 2005. På rett vei i fiskeripolitikken, Norwegian. Ålesund: Sunnmørsposten.

Næss, R. 2002. Fortellingens iscenesettelse, Norwegian. Trondheim: Norwegian University of Science and Technology, Department of Interdisciplinary Studies of Culture, Centre for Technology and Society.

Næss, R. 2003. Teknologiske Fortellinger-Den ustabile veiprising diskursen [Norwegian]. Sosiologisk tidskrift 10: 99-122.

Neumann, IB. 2001. Mening, materialitet, makt: en innføring i diskursanalyse, Norwegian. Bergen: Fagbokforlaget.

Norsk fiskerinæring. 2002. Leder Nr. 8-2002: Fornuftig strukturforslag. [Norwegian]. Råholdt: Norsk fiskerinæring.

Norwegian Coastal Fishermen's Association (NCFA). 2008. Hearing - Rekruttering i fiskeflăten - Etablering som fartøyeier, Norwegian. Ramberg: NCFA.

Norwegian Coastal Fishermen's Association (NCFA). 2011a. Årsmøte i Bø. Ramberg: NCFA. Accessed 30.09.2012. http://www.norgeskystfiskarlag.no/index.php/nyhetene/183-arsmote-i-bo.

Norwegian Coastal Fishermen's Association (NCFA). 2011b. Bank, finans og meglere tar pengene. Ramberg: NCFA. Accessed 30.09.2012. http://www.norgeskystfiskarlag.no/index.php/58-nyheter/237-bank-finans-og-meglere-tarpengene.

Norwegian Coastal Fishermen's Association (NCFA). 2011c. Fritt fiske bedre enn kvotekjøp, Norwegian. Ramberg: NCFA. Accessed 30.09.2012. http://www.norgeskystfiskarlag.no/index.php/historikk.

Norwegian Coastal Fishermen's Association (NCFA). 2012. Historikk, Norwegian. http://www.norgeskystfiskarlag.no/ index.php/historikk.

Norwegian Savings Bank Association. 2006. Hearing NOU 2006:16—Strukturvirkemidler i fiskeflåten, Norwegian. Oslo: Ministry of Fisheries and Coastal Affairs.

Norweigan Fishermen's Association (NFA). 2012. Spennende tanker fra Sp. Trondheim: NFA. Accessed 30.09.2012. http://www.fiskarlaget.no/index.php?option=com_zoo\&task=item\&item_id=1423\&ltemid=148).

Nygård, O. 2003. Exit bonde og filetienter, Norwegian. Tromsø: Nordlys. 26.02.2003.

Offshore vessel owner 17. 2011. Personal Communication.

Offshore vessel owner 18. 2012. Personal Communication.

Offshore vessel owner 5. 2011. Personal Communication.

Olsen, J. 2011. SV krever ny fiskeripolitikk. [Norwegian]. Oslo: The Socialist Party. Accessed 24.02.2012. http://sv.no/ content/view/full/31264

Ostrom, E. 1990. Governing the commons: The evolution of institutions for collective action. New York: Cambridge University Press.

Pedersen, H. 2006. Hva Må Vi Gjøre for å Sikre Lys i Husan? Norweigan. Oslo: Ministry of Fisheries and Coastal Affairs. Accessed 20.08.2011. http://www.regjeringen.no/nb/dep/fkd/aktuelt/taler_artikler/ministeren/helga_pedersen/2006/ hva-ma-vi-gjore-for-a-sikre-lys-i-husan.html?id=113908.

Prop. 1 S. 2009-2010. Proposisjon til Stortinget for Budsjettåret 2010, Norwegian. Oslo: Ministry of Fisheries and Coastal Affairs.

Rein, M. 1999. Arver jobben av pappa? - Han bror e redd for havet, Norwegian. Tromsø: Nordlys. 20.03.1999.

Remøy, PG. 2011. Personal Communication.

Sagat. 2012. Grådighet eller kvalitet i fiskerinæringen? Norwegian. Lakselv: Sagat. Accessed 05.05.2012. http://www.sagat.no/sak\&article=31169.

Sandberg, MG, and T Olafsen. 2006. Kartlegging av kompetansebehov i norsk fiskeri-og havbruksnæring, Norwegian. Trondheim: SINTEF.

Schaaning, E. 1997. Vitenskap som skapt viten. Oslo: Spartacus Forlag.

Schanche, TE. 2011. Reagerer mot APs"bortforklaring" i fiskerettighetsspørsmål. Oslo: NRK. Accessed 20.09.2012. [Norwegian] http://www.nrk.no/kanal/nrk_sapmi/1.7665956.

Seglsten, PH. 1994. Fiskelukta, Norwegian. Tromsø: Nordlys. 05.02.1994.

Singleton, S. 2000. Cooperation or capture? The paradox of comanagment and community participation in natural resource management and environmental policymaking. Proceedings from IIFET 2000. July 10-15, 2000 in Corvallis. Corvallis: Oregon State University.

Skjærvik, L. 2009. Dyr inngangsbillett til fiskeryrket, Norwegian. Trondheim: Adresseavisen. 17.04.2009.

Sønvisen, SA, JP Johnsen, and J Vik. 2011. The coastal employment system —What it was and what it is. MAST 10(1): $31-56$.

Späth, P. 2012. Understanding the social dynamics of energy regions-The importance of discourse analysis. Sustainability 4(6): 1256-1273. Accessed 30.09.2012. http://www.mdpi.com/2071-1050/4/6/1256.

St. Martin, K. 2006. The impact of "community" on fisheries management in the US Northeast. Geophys J Roy Astron Soc 37(2): 169.

Standal, D, and B Aarset. 2002. The tragedy of soft choices: Capacity accumulation and lopsided allocation in the Norwegian coastal cod fishery. Marine Policy 26(3): 221-230.

Standal, D, and IB Utne. 2011. The hard choices of sustainability. Marine Policy 35: 519-527.

Stone, D. 1989. Causal stories and the formation of policy agendas. Political Science Quarterly 104(2): 281-300.

Suarez, JL, MJ Rodriguez, and DF del Corral. 2008. The paradox of public participation in fisheries governance. The rising number of actors and the devolution process. Marine Policy 32(3): 319-325.

Troms folkeblad. 2010. Senja-ordførere bekymret for fiske-rekruttering, Norwegian. Finnsnes: Troms folkeblad. 05.10.2010. Veigård, E. 1990. Det Handler om folks selvrespekt, Norwegian. Oslo: Aftenposten. 16.01.1990.

Vestå, KIK, and OS Sundheim. 2006. Fiskeripolitikken må ta grep om kyst-norge, Norwegian. Tromsø: Nordlys. 03.10.2006. WebFinance, Inc. 2012. http://www.businessdictionary.com/. Accessed 24.03.2012.

White Paper (WP) No. 10. 1947. Om nasjonalbudsjettet 1947, Norwegian. Oslo: Ministry of Finance. 
White Paper (WP) No. 18. 1977-78. Om langtidsplan for fiskerinæringen, Norwegian. Oslo: Ministry of Fisheries. White Paper (WP) No. 20. 2002-2003. Strukturtiltak i kystfiskeflåten, Norwegian. Oslo: Ministry of Fisheries. White Paper (WP) No. 21. 2006-2007. Strukturpolitikk for fiskeriflaten, Norwegian. Oslo: Ministry of Fisheries. White Paper (WP) No. 32. 1989-90. Framtid i Nord. Levekär og framtidsutsikter i Nord-Troms og Finnmark, Norwegian. Oslo: Ministry of Local Government and Regional Development.

White Paper (WP) No. 32. 1990-91. På rett kjøl - Om kystens utviklingsmuligheter, Norwegian. Oslo: Ministry of Local Government and Regional Development.

White Paper (WP) No. 51. 1997-98. Perspektiver på utvikling av norsk fiskerinæring, Norwegian. Oslo: Ministry of Fisheries. White Paper (WP) No. 62. 1953. Om et langtidsprogram for 1954-1957, Norwegian. Oslo: Ministry of Finance. White Paper (WP) No. 75. 1962-63. Statens fiskarbanks virksomhet i regnskapsåret 1962, Norwegian. Oslo: Ministry of Fisheries.

White Paper (WP) No. 93. 1982-83. Om retningslinjer for fiskeripolitikken, Norwegian. Oslo: Ministry of Fisheries. Wilson, DC. 2009. The paradoxes of transparency-Science and the ecosystem approach to fisheries management in Europe. Amsterdam: Amsterdam University Press.

Woodak, R. 2007. Critical discourse analysis. In Qualitative research practice, ed. C Seale, G Gobo, JF Gubrium, and D Silverman, 185-201. London: Sage.

World Wildelife Fund (WWF). 2006. Hearing—NOU 2006:16—Strukturvirkemidler i fiskeflåten, Norwegian. Oslo: Ministry of Fisheries and Coastal Affairs.

Wright, M. 2001. A Fishery for Modern Times. St. John's, Newfoundland: Oxford University Press.

doi:10.1186/2212-9790-12-8

Cite this article as: Sønvisen: Recruitment to the Norwegian fishing fleet: storylines, paradoxes, and pragmatism in Norwegian fisheries and recruitment policy. Maritime Studies 2013 12:8.

Submit your manuscript to a SpringerOpen ${ }^{\circ}$ journal and benefit from:

- Convenient online submission

- Rigorous peer review

- Immediate publication on acceptance

- Open access: articles freely available online

- High visibility within the field

Retaining the copyright to your article

Submit your next manuscript at $\gg$ springeropen.com 